\title{
Students' Voices on an English Material for Accounting Major At SMK Negeri 2 Kota Jambi
}

\author{
Suyadi $^{*}$, Mustika ${ }^{2}$ \\ ${ }^{1,2}$ Universitas Batanghari Jambi \\ *Correspondence email: suyadi@yahoo.com; kittymustika@gmail.com
}

\begin{abstract}
English for specific purposes which is aimed at developing a specific English material for the students of accounting major is important aspect due to as the specification of materials for teaching English at Vocational Senior High School 2 is needed by the students. This research is aimed at the students' voices on the specific material needed by the students at accounting major would be become an end result of English teaching material. This research is aimed at finding specific English materials for accounting major at Vocational Senior High School 2 of Jambi City. Some structured-questions were distributed to arrange the students' interests of the specific materials. This research was conducted in two classes of SMK Negeri 2 Kota Jambi using a qualitative research. A thematic analysis was implemented in relation to the specific English materials used in the classroom. The findings reveal that some materials are matched with accounting major but some others are not. The materials for accounting major are compiled in a handbook of English material for accounting students which are two chapters of materials; Introduction to Accounting and Conceptual Framework of Accounting.
\end{abstract}

Keywords: structured, major; vocational; needs; specific materials

\begin{abstract}
Abstrak. Materi pembelajaran Bahasa Inggris untuk tujuan khusus sangat diperlukan oleh setiap institusi pembelajaran agar tercapai tujuan pendidikan secara khusus. Untuk tercapainya tujuan tersebut maka dibutuhkan suatu kajian yang mendalam mengenai materi khusus untuk mata pelajaran Bahasa Inggris Jurusan Akuntansi terutama pada SMK Negeri 2 Kota Jambi. Penelitian ini merupakan lanjutan dari penelitian terdahulu yang telah dilaksanakan oleh Peneliti, yang mana didapati bahwa siswa-siswi tersebut membutuhkan materi khusus dalam pembalajaran Bahasa Inggris pada Jurusan Akuntansi. Dengan menggunakan pertanyaan yang terarah kepada para siswa-siswi maka didapati dua materi utama yang mereka butuhkan untuk pembelajaran Bahasa Inggris yaitu Introduction to Accounting (Pengenalan Akuntansi) dan Conceptual Framework of Accounting (Kerangka Pemikiran Akuntansi).
\end{abstract}

Kata Kunci: pertanyaan terstruktur; jurusan; kejuruan; kebutuhan; materi khusus

\section{INTRODUCTION}

Learning English as a Foreign Language is not difficult even has its own challenges to learn and understand comes together into students' mind. When students complain about how difficult to understand a second/foreign language (Hymes, 2015) at the same time students are talking about difficulty of finding the correct words and using the correct sentence with the correct grammar in line with the difficulty of expressing ideas (Payne and Turner, 1999). By having correct grammar, the teachers share and transform the knowledge the correct understanding of the language.

Sharing and transforming knowledge to learner need a long process of learning which means a transformative process of taking in information internalizes and mixes with what the learners have experienced changes and what the learners know and builds on what the students do (Bingham and Conner, 2010). The process of learning is based on input, process, and reflection.

In almost the same sound, Ambrose (2010) explains that learning is a process that leads to change, which occurs as a result of experience and increases the potential of improved performance and future learning. To arouse learning English seems to be based on the students' future learning intention. For example, the students of accounting seem to be motivated in learning English if the learning materials have a tight relationship with their major. Accounting as one major of program in SMK Negeri 2 Kota Jambi has crucial needs for specific English materials occupy in the classroom. The previous results of my research showed that accounting students needs specific English materials to be used in their classroom.

To response the previous research results, the researcher conducted another research only to find out what kinds of materials that the students of accounting really need to learn. It is hoped that by having the results through this research, the researcher is able to arrange a new English material for accounting students. It is also hoped that the results would be applicable into the classroom and could motivate the students to improve their English skills ability.

In this case, English becomes one of the most important subjects of language education for students in Indonesia. Therefore, before learning, keep in mind that the material studied already in accordance with the students' needs. To achieve effectiveness and alignment between the needs and the ability of students, it is 
necessary to conduct a research on the needs of students in learning English in college.

In English for Specific Purposes (ESP), English is taught to meet students' needs in learning English suits to their specialization. The needs in area of specialization are worthy considering since the language we speak and write varies from one context to another (Hutchinson and Waters, 1987). Further, if a group of learners' English language needs can be accurately specified, it will be easy to determine the content of a language program that will meet these needs.

Suyadi (2016) states that English needs a specific method and materials of teaching and learning in order to make more useful for the learners and not wasting time of teaching the students. To make it more useful, of course, the teachers of English need to consider the basic needs of the students in learning the English at their classroom. Specific English materials should be used for a specific study program of the students. In other words, every study program should have its own specification of English materials.

Students' needs of English in specific discipline can be analyzed through Needs Analysis (Richard, 2001). Needs analysis is used to develop objectives and content, and it can provide data for reviewing an existing program (Richards in Nunan, 1988). According to Iwai et al. (1999) cited in Songhori (2008), the term of "needs analysis" generally refers to the activities that are involved in collecting information that will serve as the basis for developing a curriculum that will meet the needs of a particular group of students. Moreover, Spratt (2005) said:

Students' personal needs, teacher should choose suitable materials, topic, speed of lesson, activities, approach to teaching (activity-based, topic-based), treatment of individual learners, skills, interaction patterns (group, pair or individual), and types of feedback. Meanwhile, in order for teacher to meet students' learning needs, they should choose suitable materials and topic, activities, interaction pattern, approach to teaching, language and skills level of language and skills, learning strategies and workload.

It means identifying students' needs are crucial to design English for Specific Purposes (ESP) course in terms of deciding suitable materials. Students' needs analysis is often described as the first step that the curriculum or course planners should do to determine the students' skills, competences, knowledge, needs and purposes in learning. This step helps the curriculum planners or learning provider knew whether the content of the courses is relevant with the students' needs or not. Furthermore, according to Richards (2001), Students' needs in English for Specific Purposes (ESP) are described in terms of performance, that is, in terms of what the learner will be able to do with the language at the end of a course of study. In many cases, students' needs may be relatively easy to determine, particularly if learners need to learn a language for very specific purposes, for example, employment in fields such as tourism, nursing, accounting or the hotel industry (Richards, 2001).

Richards (2001) further says that needs analysis in language teaching may be used for a number of different purposes. For example, to find out what language skills a learner needs in order to perform a particular role, such as sales manager, or tour guide; to identify a gap between what students are able to do and what they need to be able to do; to collect information about a particular problem learners experience; to determine which students from a group are most in need of training in particular language skills, and to identify a change of direction that people in reference group feel is important.

Needs itself, are often described in terms of a linguistic deficiency, that is, as describing the difference between what the learners can presently do in a language and what the learners should be able to do. What are identified as needs depends on a judgment and reflects the interest and values of those making such a judgment. Teachers, learners, employers, parents, and other stakeholders may thus have different views as to what needs are. Conelly and Clandinin (1988) define a stakeholder as a person or people with a right to comment on, and have input into, the curriculum process offered in schools. Different stakeholders may want different things from the curriculum. In addition, Brindley (1984) says,

"The term need is not as straightforward as it might appear, and hence the term is sometimes used to refer to wants, desires, demands, expectation, motivations, lacks, constraints, and requirements".

In an educational setting, a students' needs analysis helps students identify where they are in terms of their knowledge, skills and competences, where they wish to be and their learning goals. It is related to the statement that adults learn better when they can see a reason why they are following a program of study and find the relevance between their purpose in learning and the content of the study that they must learn. The information from the needs analysis will also be used to formulate a syllabus and develop teaching material.

According Hutchinson and Water (1987) target needs is defined, as an umbrella term that includes three distinctions: necessities, lacks, and wants. SMK N 2 Kota Jambi has some departments such as accounting, tourism, and secretary. Some students tell if they need specific materials in learning English because they have difficult when their practical work. 
Based on the fact above, the researcher takes much interest in conducting the research dealing with English for Specific Purposes (ESP), especially on the learners needs. Here the researcher wants to examine the learners' needs of English for Specific Purposes (ESP) at SMK N 2 Kota Jambi especially in accounting program because English is important for SMK N 2 Kota Jambi students since many technical accounting books are written in English and they are ready for their practical job that required English mastery.

In analyzing the data, this research is using qualitative method which is based on the students' voice on the English material used in the SMK Negeri 2 Kota Jambi. Using descriptive qualitative method explains the problem solving. Creswell (2012) perceives "A qualitative research study is needed to explore this phenomenon from the perspective of distance education students'. This research is not only a sample of colleting the data, but covers data analysis, and interpretation to the research problem can also be concluded also not qualitative not only search data but also data can be problem solving the research. Beverley Hancock (2009:7) said that qualitative research is concerned with developing explanations of social phenomena. That is to say, it aims to help us to understand the social world in which we live and why things are the way they are.

The conclusion of the above argument, qualitative descriptive is the research to describe the research subject by collecting data of students' voices on English material for accounting students. Their opinions toward learning process in the classroom.

\section{METHOD}

In analyzing the data, this research is using qualitative method which is based on the students' voice on the English material used in the SMK Negeri 2 Kota Jambi. Using descriptive qualitative method explains the problem solving. Creswell (2012) perceives "A qualitative research study is needed to explore this phenomenon from the perspective of distance education students'. This research is not only a sample of colleting the data, but covers data analysis, and interpretation to the research problem can also be concluded also not qualitative not only search data but also data can be problem solving the research. Beverley Hancock (2009:7) said that qualitative research is concerned with developing explanations of social phenomena. That is to say, it aims to help us to understand the social world in which we live and why things are the way they are.

The conclusion of the above argument, qualitative descriptive is the research to describe the research subject by collecting data of students' voices on English material for accounting students. Their opinions toward learning process in the classroom.

\section{FINDINGS}

Part A: Indicator 1: General Information
General Information is divided into five item, they are gender, identity of respondent, length of learning English, courses that the students ever studied before and level of English language skills. In gender information, the researcher wanted to know the sum of male and female students in order to know the teaching and learning process in the classroom of accounting. In identity item, the information that the researcher wanted to know is about the name of the participant, their study programs involved the university's name and semester where they are now. In the length of learning English item, the researcher wanted to know the period of time the students started learning English. Whereas, in the courses that the students ever taken before, the researcher wanted to know whether the students' knowledge of English could help them in learning English at accounting program. Then, in the level of English language skill item, the researcher wanted to know whether the students' language skills in English could motivate them to learn English. Those items were taken by using questions as the basic identification of the students' background knowledge for studying English at accounting department program. The basic identification was used to be a variable that is affected the students' achievement as they were used as an analysis below:

Identity was divided into male and female. Participants were 46 students the result showed that Male students were 20 while Female students were 26 persons. It means that mostly female students are interested in choosing accounting program where $55.52 \%$ shown in the diagram and $43.48 \%$ male students.

From the figure 1 above, it is shown that most of the female students are dominated accounting program compared to the male students.

In the length of learning English item, it is found that there are 31 students or $67.39 \%$ from the total students ever taken English course since they have been in $4^{\text {th }}$ grade of Primary School. It was due to the government put English as a compulsory subject in Indonesia, so, some schools put English into their school curriculum. It is only 15 students or $32.61 \%$ of the student started learning English at Junior High School, no one of the student started learning English at Senior High School, neither never had English before.

Based on the above figure, it is clear that most of the students at accounting program started learning English at $4^{\text {th }}$ Grade of Primary School even though their knowledge of English could not much help them in understanding English.

Whereas, in the item of English course which ever been taken by the students, it is proven that 29 students or $63.04 \%$ never had an English course before. Three students or $6.52 \%$ had ever taken an English course at Conversation class, four students or $8.69 \%$ ever had taken Intermediate class, with 6 students or $13.04 \%$ ever had Elementary class, and finally three students or 
8.69\% ever had an English course at Primary class. The following figure expresses the data above.

To complete Part A for general information, the researcher asked the students about the level of Englishlanguage skill that the students perceived to have.
English-language skills which are included in the questions are Listening, Speaking, Reading, Writing, and also Translation, Vocabulary and Pronunciation. The following figure describes about it.

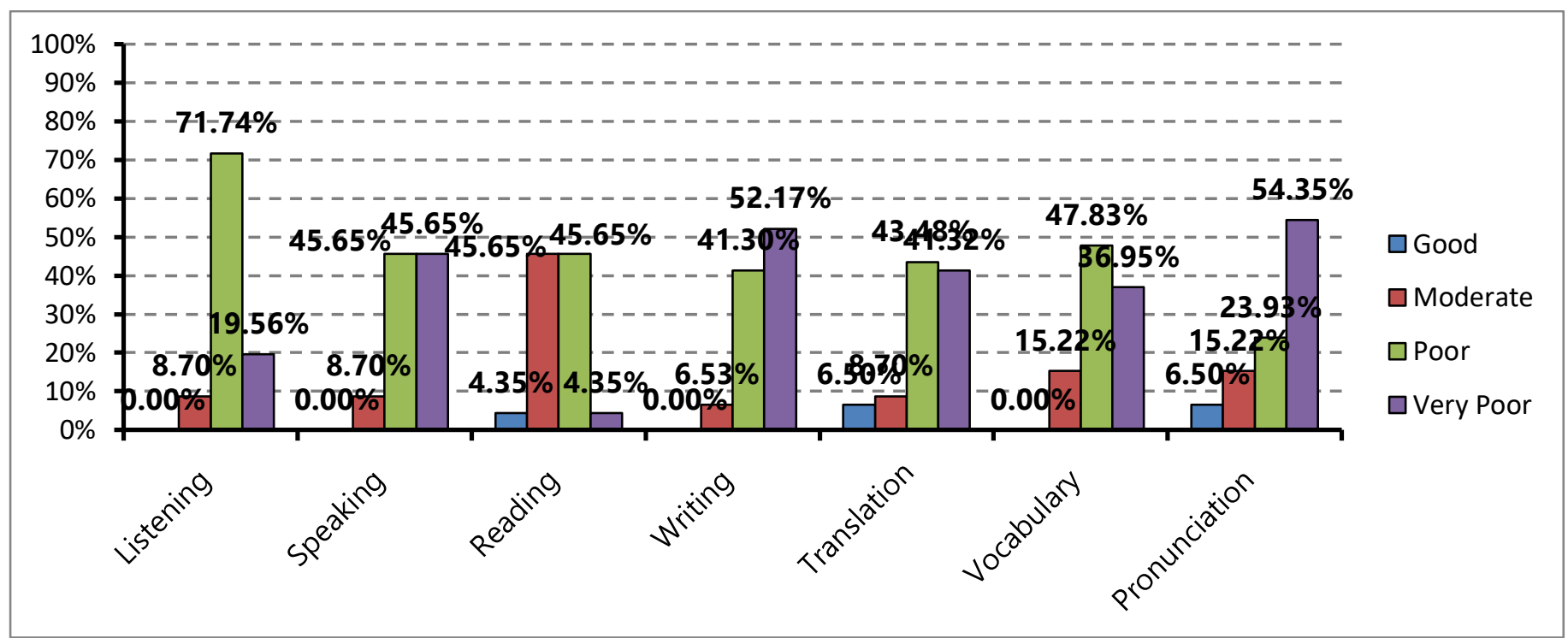

Figure 1: English Language Skill Level

The above figure revealed that only two or $4.35 \%$ students felt that their Reading skills is 'Good', three students or $6.5 \%$ students felt also 'Good' in their Translation, and only three or $6.5 \%$ students who also felt 'Good' in their Pronunciation in English. It means that only about three students who felt 'Good' in only at three skills of English. Whereas, at the skills such as Listening, Speaking, Writing, and Vocabulary there were no one felt 'Good'.

The level of English-language skills which dominated the 'Very Poor' categories are Writing with 24 students or $52.17 \%$, Pronunciation with 25 students or $54.35 \%$, Speaking with 22 students or $45.65 \%$, Translation with 19 students or $41.32 \%$, Vocabulary with 17 students or $36.95 \%$, Listening with 9 students or $19.56 \%$, and Reading with 2 students or $4.35 \%$.

From the general information that the researcher found is that the students need the all language-skills in English to improve their English at Accounting Program. It means that for the future English materials should involve the all language-skills in English in order to motivate the students in learning English. Based on those reasons, the researcher needs to develop a new English material for Accounting Program.

\section{Part B: Indicator 2. Target Needs}

In Part B is called as Indicator 2 which consists of 17 questions divided into three (3) sections namely, Lacks, Necessities, and Wants. Section 1 was Lacks consisted on eight questions as described below:

\section{Section 1: Lacks}

The results of questionnaires shown that the question number 1, "Does the English subject meet your needs regarding the use of the English language?" got the answer of 'Adequately' is 20 students or $43.48 \%$ which is meant that the previous English materials was not fully met the needs of the students at Accounting Program. It was also supported by the answer of 'Not Much' with 6 students or $13.04 \%$ showed that the previous English materials was not fully met the needs of Accounting Program at University of Jambi. Fortunately, there was no one saying that the previous English materials was 'Not at all', it means that even it was not fulfilling the students' needs for accounting program, but it was still fulfilled the basic needs of English.

The question number 2 is about the receptivity of the students to the previous English materials shown that 37 students or $80.43 \%$ answered with 'High' category, 'Indifferent' category reached 9 students or $19.57 \%$, and no one answered the category 'Very High'. It was shown that the previous materials were easy to be received by the students as they could give comments that the previous English materials were not matched with their study program.

The question number 3 is about the students' participation in the process of teaching and learning which was revealed there were 23 students or $50 \%$ answered 'Seldom' to contribute their specific knowledge and personal experience in the classroom. There were 4 students or $8.70 \%$ answered 'Never' had a chance to contribute their knowledge and personal experience in the classroom. It was only 6 students or $13.04 \%$ who answered 'Always' category to the 
question. It means that the involvement of the specific knowledge of the students in the process of teaching and learning is very important in order to improve the students' target knowledge of study program. The following figure described the above arguments.

The question number 4 expressed the students' independency to read English text. It was revealed that 28 students or $60.87 \%$ answered 'No' independency after learning the previous English materials, moreover, if it is related to the specific knowledge of accountancy.

In the question number 5, the students were asked about the expectation after they learnt English whether they could be able to use more texts in English or not especially dealt with their study program at accounting. The result shown that 30 students or $65.22 \%$ of them answered 'Yes', with 6 students or $13.04 \%$ answered 'No', whereas another 10 students or $21.74 \%$ answered 'Don't Know' category. Those results revealed that the students' needs of English materials was to use more texts in English, but the previous materials were not completing their needs, or in another words that the students' 'Lacks' of learning English materials was really occurred. For this reason, the researcher concluded to produce a product of teaching English for Accounting Program. The following figure proved those realities.

Then, for the question number 6 , the researcher asked the students whether English materials could help them in improving the students' ability English skills. The answering category of 'A Lot' has dominated the students' answers especially for 'Translation' skills which got 26 students or $56.52 \%$. It means that the students need to translate in learning English in order to help them to understand. Vocabulary was also got higher percentage of the students' answer with 23 students or $50 \%$ were choosing this category which means that they needs to know more vocabulary relates to accountancy. The following figure was shown those reasons.

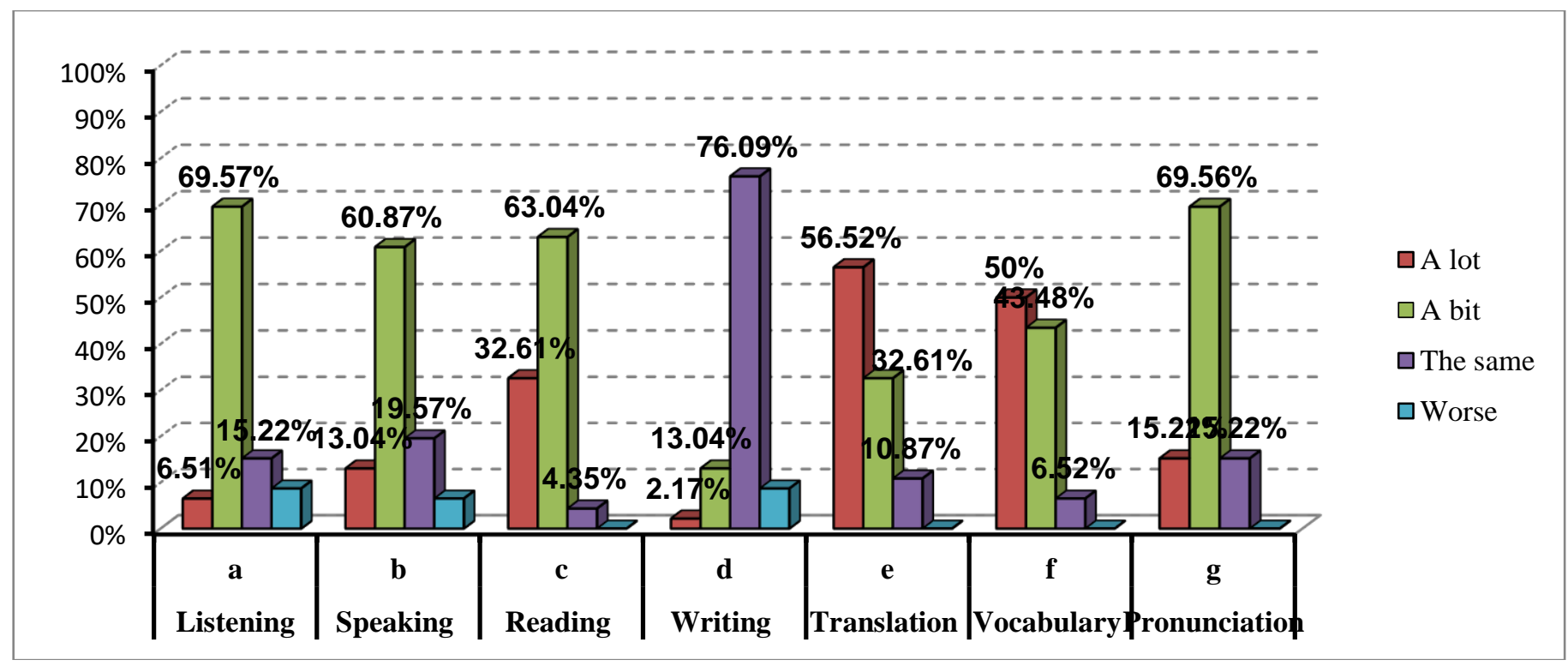

Figure 2: English Skills help the Students’ Lacks

The question number 7 was asked the student basic knowledge of English when they started learning at Accounting Program. It was only 1 student or $2.17 \%$ who answered that his knowledge of English was 'Excellent' which contradicted to the students who answered 'Weak' with 20 students or $43.49 \%$. This reality shown that the students' English skills were not helping them to improve the knowledge of English even after they learnt at Accounting Program. For this reason is shown in Figure 2.

When the students were asked about whether English subject should appear or not appear in the school curriculum of Accounting Program, they still want to have English as an 'Obligatory' subject in the Faculty with 33 students or $71.74 \%$. Even there were 5 students or $10.87 \%$ wanted to delete the English subject from Faculty curriculum.
Based on the data gathered above, it was clear that the target needs in section 1 'Lacks', that the students' weaknesses on the English skills are proven. So, the researcher comes to the conclusion to overcome the weaknesses by developing students' book which covers the four skills of English completed with Vocabulary, Translation and Pronunciation. Those skills would be combined with the target knowledge of accountancy to support the students' study program.

\section{Section 2: Necessities}

Section 2 was Necessities which has 6 questions. The purpose of this section was to find out the students' necessities to study English at Accounting Program. The results of the questionnaire were shown that each skill of English has different percentage. As in the question number 1 , the students felt necessary to understand spoken skill in English with the 31 students or $67.40 \%$ 
wanted it to be appeared in the teaching materials at Accounting Program. Understanding Reading strategies was also had higher choices with 23 students or $50 \%$. It means that the students felt necessary to build up reading texts on the English materials at Accounting Program in order to meet their target knowledge in study program. evidence.

The following question and figure were shown the

"In English course, which of the following objectives do you consider most appropriate to meet your needs": a. Understanding spoken in English $=31(67.40 \%)$

b. Knowing the grammatical structures of the language $=23(50 \%)$

c. Developing reading strategies $=23(50 \%)$

d. Translating some English texts into Bahasa Indonesia $=17(36.96 \%)$

e. Speaking English $=17(36.96 \%)$

f. Writing in English $=13(28.26 \%)$

g. Other(s). Please specify

\section{English Skills Necessities}

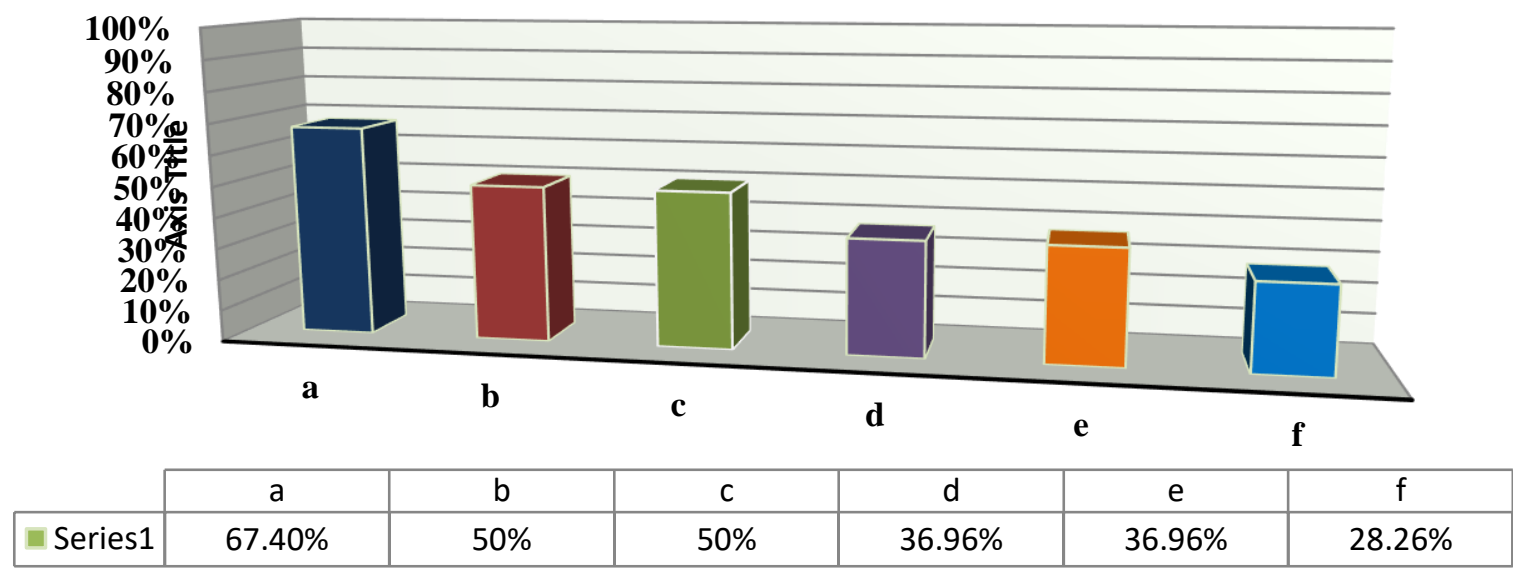

Figure 3: English Skills Necessities

In the question number 2 which was asked the students about the importance of the English skills to their academic successes. The answers were shown that Reading skill had 29 students' answers or $63.04 \%$ to say that it is 'Very Important' to have in Accounting Program. On the contrary on Writing skill which had no one saying that it was 'Very Important' materials to have in Accounting Program. Meanwhile, Pronunciation had 3 students' answers or $6.52 \%$ that was saying 'Not Important' to have in Accounting Program. The following figure was shown this proof.

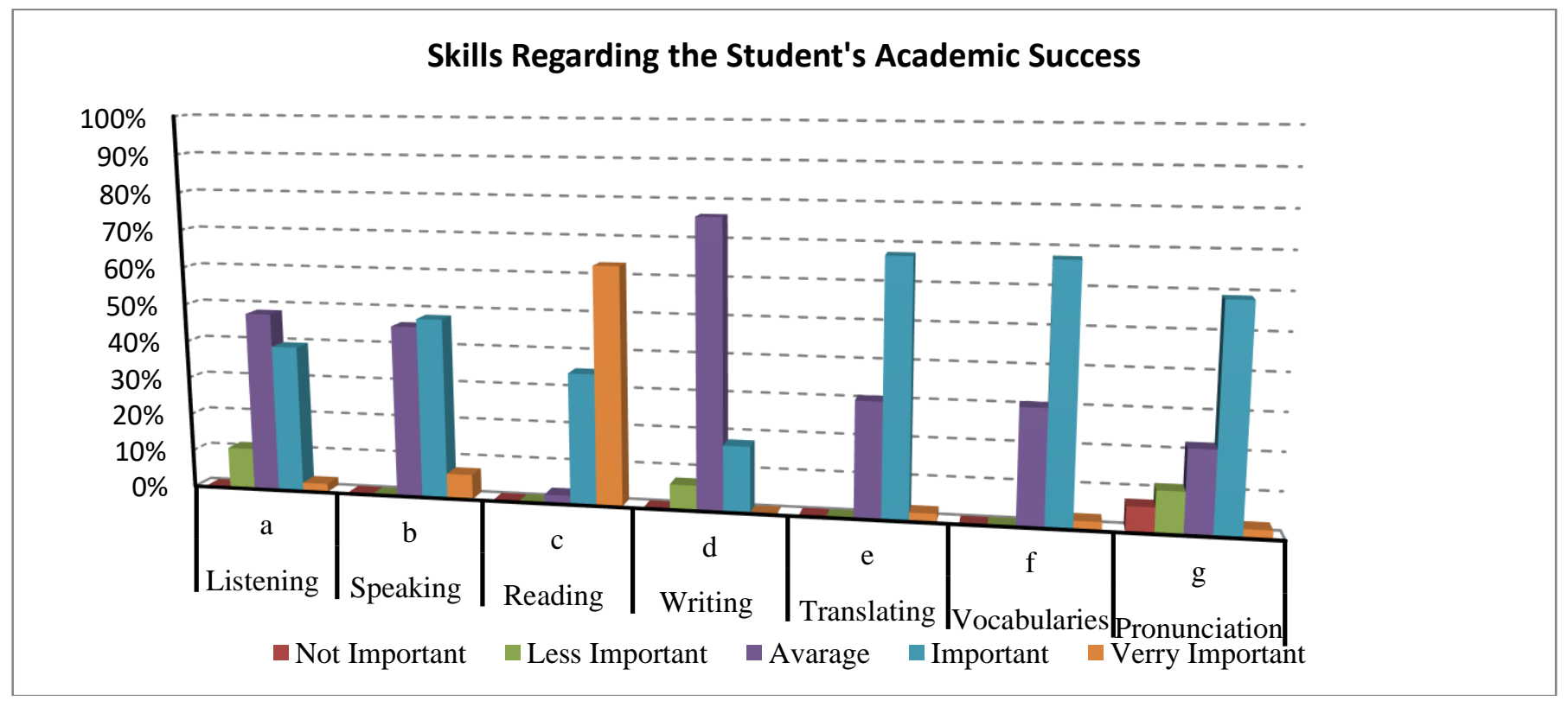

Figure 4: Skill Regarding the Students' Academic Success 
When the students were asked about what they wanted to manage after completing English course, surprisingly, 36 students or $78.26 \%$ of them wanted to make an outline for presentation, report or project in accounting work. From this result it was revealed that writing and speaking skills are needed to be taught at Accounting Program in order to realize their ambition on their future works.

"You think that as a result of this course you manage to":

a. Develop your academic purpose $=24(52.17 \%)$

b. Making an outline for a presentation, report or project in accounting $=36(78.26 \%)$ c. Understanding and verbalizing common forms in accounting $=23(50 \%)$

d. Find relevant information $=6(13.04 \%)$

e. Make summaries $=8(17.39 \%)$

f. Use reading strategies $=6(13.04 \%)$

g. Use the dictionary $=4(8.70 \%)$

h. Develop your own way of reading $=4(8.70 \%)$

i. Get to know the English language better $=13$ $(28.26 \%)$

j. None of the above $=0$

k. Other (s). Please specify $=0$

The following figure was shown that reason.

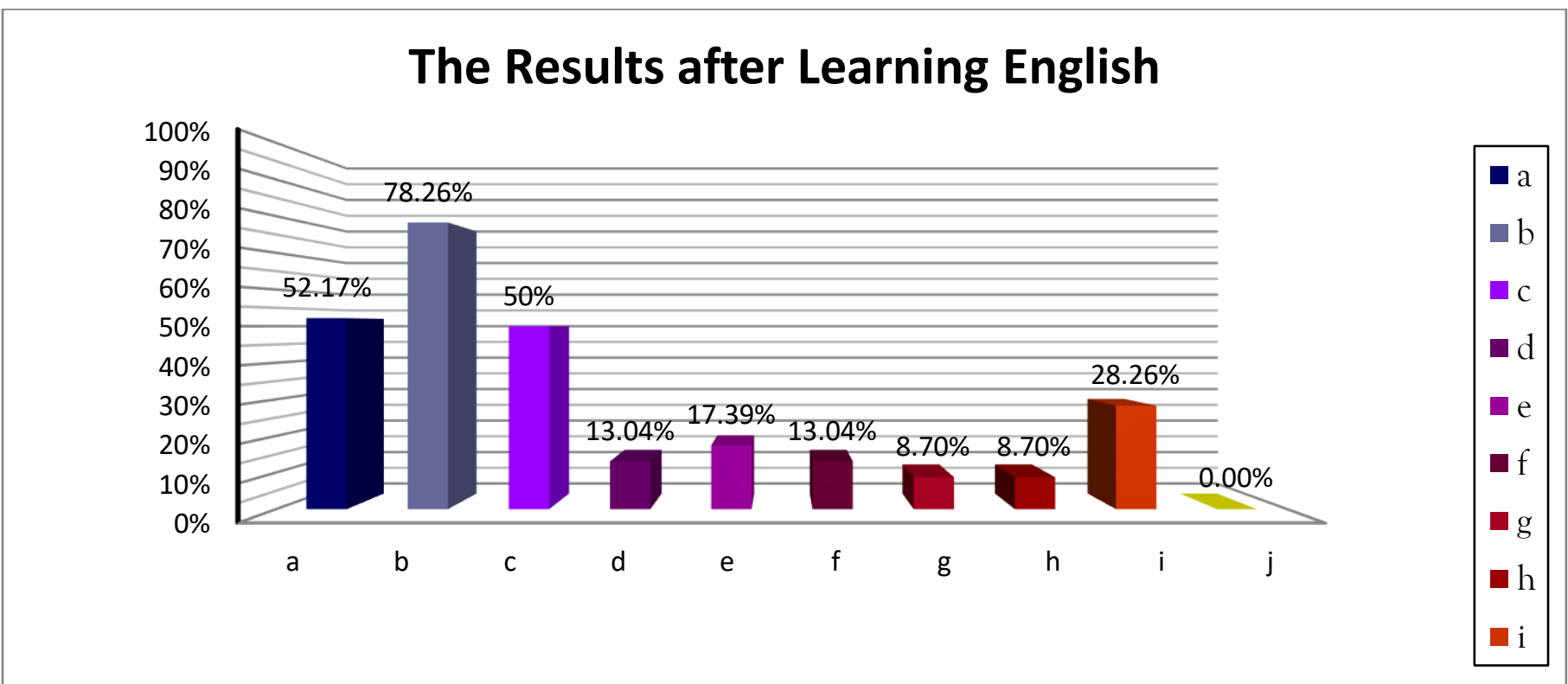

Figure 5: The Results after Learning English Manage to.

Based on those data were gathered, the students' necessities on English skills were very important to be included on the text book especially which are related to their study program at accountancy. Vocabulary, Translation and Pronunciation are also important to meet the students' necessities in learning English. Those English skills were not existed fully in their previous materials.

After analyzing those data, so the researcher came to the conclusion that an apt English material for Accounting Program is need to be produced.

Section 3 was named as Wants which had 3 questions. In this section, the researcher wanted to find out the students' desires in learning English especially it is correlated with their accounting study program. The very surprisingly result was that 40 students or $86.96 \%$ answered that 'Learning English seems to be: Useful for getting a job'. It means that the students wanted to have a good job in accounting work which becomes their study program at SMK Negeri 2 Kota Jambi.

This result is displayed in the following figure.

"Learning English seems to you to be": a. Preparation to meet the needs of the consumer society $=18(39.13 \%)$

b. A means for spreading the imperialist domination of other nations $=2(4.35 \%)$

c. A way of getting to know other peoples $=3(6.52 \%)$

d. A means of access to the specific bibliography in your area $=36(78.26 \%)$

e. A means of access to any text in English $=13$ $(28.26 \%)$

f. Useful for getting a job $=40(86.96 \%)$

g. Other (s). Please specify $=0$

The question number 2 was about 'Learning English should improve the students' target knowledge in accounting", had the answers of 28 students or $60.87 \%$ saying that it was important to have in English materials. Another 18 students or $39.13 \%$ answered it was 'Very Important' to include the accountancy knowledge at the English subject materials in order to match between the students' target knowledge and the English knowledge. For this evidence, the following figure could answer it. 


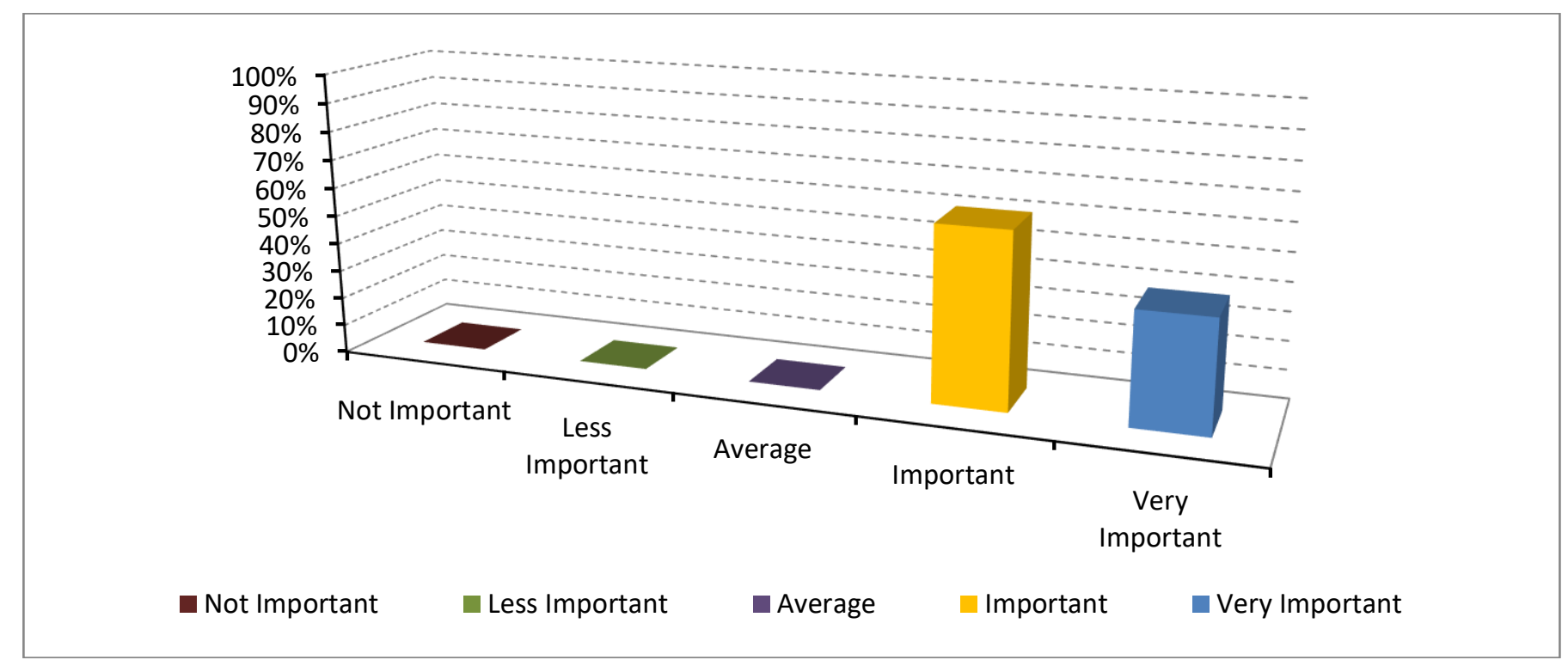

Figure 6: English should improve the students' target knowledge

To complete the students' desires on learning English at Accounting Program, they proved by giving the answers of the question number 3, "Learning English should combine between the target knowledge and the English skills". Twenty-eight students or
$60.87 \%$ was saying that Reading was very important to have in English materials and it should be completed with Vocabulary with 20 students or $43.48 \%$ were saying it was very important.

The following figure was shown to this reason.

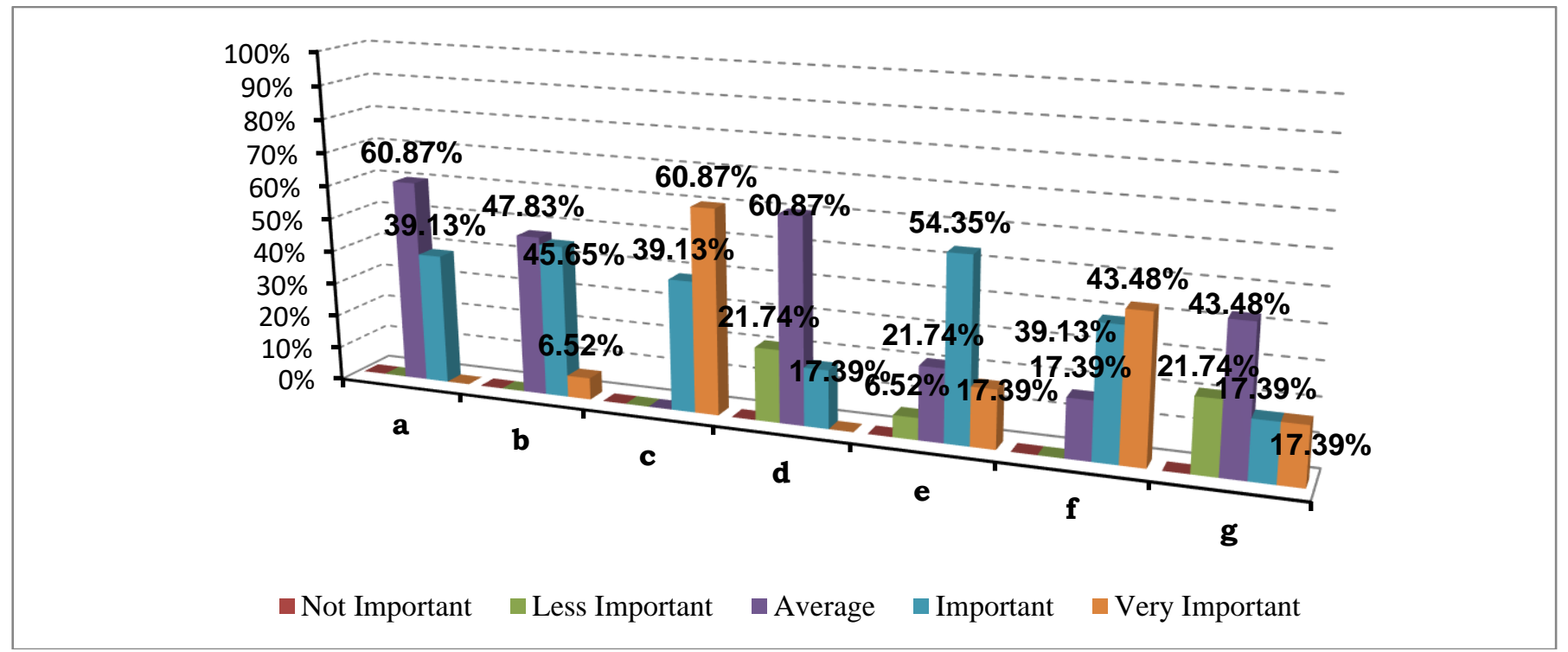

Figure 7: English should be combined with the target knowledge of accounting.

Note:

a. A for Listening

b. B for Speaking

c. C for Reading

d. D for Writing

e. E for Translation

f. F for Vocabulary

g. $\mathrm{G}$ for Pronunciation

Based on the data was collected using the questionnaire above, the students wanted to get the knowledge of English while getting the knowledge of their target knowledge of accountancy in order those knowledge to be applied in their future work. Then, the combination between the knowledge of English and the knowledge of accountancy would create a new zest for the students to learn English while building up their main study program as well.

\section{Part C: Learning Needs \\ Section 1: Materials}

Indicator 3 was divided into two main sections. In Section 1: Materials, which was divided into two items, first, asking about the types of materials that could be suit to be included at Accounting Program. Second item was asking about the specific materials which were 
supposed to be learnt in the classroom activities. These specific materials would be the topics for the textbook.

The question about "What types of materials do you think the accounting program should include?". Point a) the type of textbooks and syllabus had 36 students or $78.26 \%$ answers saying that it was very important to be included. While another 10 students or $21.74 \%$ answered that textbooks and syllabus were important to be included. No one answered this type was not important, less important and average. It means that the students' learning needs on Section 1 or materials was textbooks.

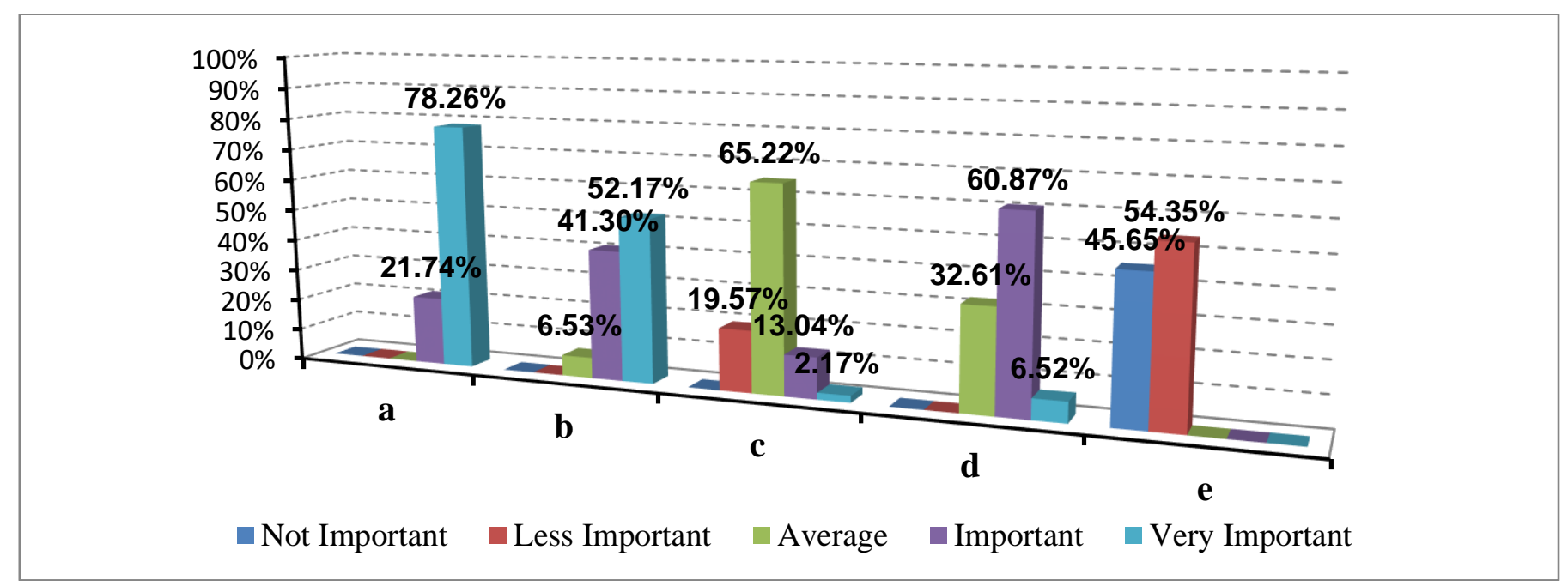

Figure 8: Types of materials should be include

Notes:

a. Textbooks and syllabus

b. Kind of forms used on job

c. Video tapes

d. Booklets

e. Tutorial

While in the point b) kind of forms used on job such as journal, ledger, bank notes, etc., had 24 students' answers or $52.26 \%$ of 'Very Important' category, 19 students or $41.30 \%$ answered for 'Important' category, and 3 students or $6.52 \%$ chose 'Average' category. From these results, it was clear that these kind of forms were needed to be included in type of materials should be used in the classroom activity. No one answered for the categories of 'Not Important' and 'Less Important' was only to convince that these kinds of forms were useful for the students of accounting.

In the point c) was about "video tapes relating to accounting and business in general", had no one answered for 'Not Important' category and 9 students or $19.57 \%$ answered 'Less Important' category which means that it was useful to include video tapes on the process of teaching and learning English at Accounting Program. It was supported with 30 students or $65.22 \%$ answered 'Average' category, with 6 students or 13.04\% were saying 'Important' category, and only one student or $2.17 \%$ who said it was 'Very Important' to use video tapes in the classroom for accounting.

Point d) "Booklets" had 27 students or $58.70 \%$ answers 'Less Important' category, two students or 4.35\% answered 'Not Important' category which was meant that 'Booklets' was not really important to be used in the classroom activity.
Whereas in point e) 'Tutorial' had 21 students or $45.65 \%$ answers for 'Not Important' category and 25 students or $54.35 \%$ for 'Less Important' category which were meant that 'Tutorial' was not really need to be included in the classroom activity at accounting program while learning English.

\section{CONCLUSION}

The researcher came to the conclusion that creating a textbook for English materials for accounting major was really important. It should be completed with discussing some authentic materials in it, using some videos visual, and no tutorials.

The second item in the third indicator was "Specific topics for learning English at Accounting Program should be". This item was divided into eight topics which were proposed to be included in the teaching materials at accounting program. The students were asked to choose the categories of 'Not Important', 'Less Important', 'Average', 'Important', or 'Very Important', to form their opinions on the future topics for learning English at accounting major.

In this item, there were eight points that were asked to the students to choose. The eight points were about the topics of the proposed English textbook which would be produced. The eight points were a) Introduction to Accounting, b) Conceptual Framework of Accounting,

Point a) was asking about "Introduction to Accounting" had 43 students or $93.48 \%$ answered to the category of 'Very Important' and 3 students or $6.52 \%$ answered to the category of 'Important'. No one answered 'Not Important', 'Less Important', and 
'Average' categories. Based on these proofs, it was clear that "Introduction to Accounting" was really needed to be existed in the textbook of English for Accounting.

Point b) was asking about "Conceptual Framework of Accounting" had 42 students or $91.30 \%$ answered to the category of 'Very Important' and 4 students or $8.70 \%$ answered to the category 'Important'. No one answered to the categories of 'Not Important', 'Less Important', and 'Average' which were meant that this material was needed to be included in the textbook of English for Accounting.

Point c) was asking about "Basic Accounting Procedures" had 43 students or $93.48 \%$ answered to the category of 'Very Important' and only 3 students or $6.52 \%$ answered to the category of 'Important'. Seeing from this evidence, it was clear that this topic was needed to be included in the textbook of English for Accounting. Meanwhile, in the categories of 'Not Important' and 'Less Important', there were no one answered on them.

In point d) was asking about "Journal" had 36 students or $78.26 \%$ answered to the category of "Very Important' and 7 students or $15.22 \%$ answered to 'Important' category which were meant that 'Journal' was need to be included. One student or $2.17 \%$ answered to the category 'Less Important', 2 students or $4.35 \%$ answered to the category of 'Average', and no one answered to the category of 'Not Important'. Based on these data, it was very convincing that "Journal" was needed to be included in the textbook of English for Accounting.

Point e) was asking about "Ledger" had 30 students or $65.22 \%$ answered to the category "Very Important' and 14 students or $30.43 \%$ answered to 'Important' category which were meant that "Ledger" was needed to be included in the textbook of English for
Accounting. Only one student or $2.17 \%$ said that it was 'Average' and one student or $2.17 \%$ said that it was 'Less Important', and no one answered that 'Ledger' was 'Not Important'.

Point f) was asking about "Bank Reconciliation Statement" had 27 students or $58.83 \%$ answered to the category of 'Very Important' and 15 students or 32.61\% answered to the category of 'Important'. The data was shown that this topic was needed to be included to the textbook of English for Accounting as one of the material at Accounting Program. Four students or $8.70 \%$ gave the answer to the category of 'Average' and no one answered for 'Not Important' and 'Less Important' categories. From this data, it was clear that "Bank Reconciliation Statement" as one of the topic was needed to be included in the textbook of English for Accounting.

In the point g) was asking about "Capital and Revenue Transaction" had 22 students or $47.83 \%$ answered to the category of 'Very Important' and 21 students or $45.65 \%$ was saying that it was 'Important'. Only 3 students or $6.52 \%$ answered to the category of 'Average', with no one said 'Not Important' neither 'Less Important'. From this data, it was clear that "Capital and Revenue Transaction" was needed to be included in the textbook of English for Accounting.

The point h) was asking about "English skills should be combined with the accounting knowledge" in the textbook of English for Accounting was also had 23 students or $50 \%$ to the category or 'Very Important' and 23 students or $50 \%$ to the category of 'Important'. From this data, it was clear that the combination of the accounting knowledge and the English skills were very important to be integrated in the textbook of English for Accounting at University of Jambi.

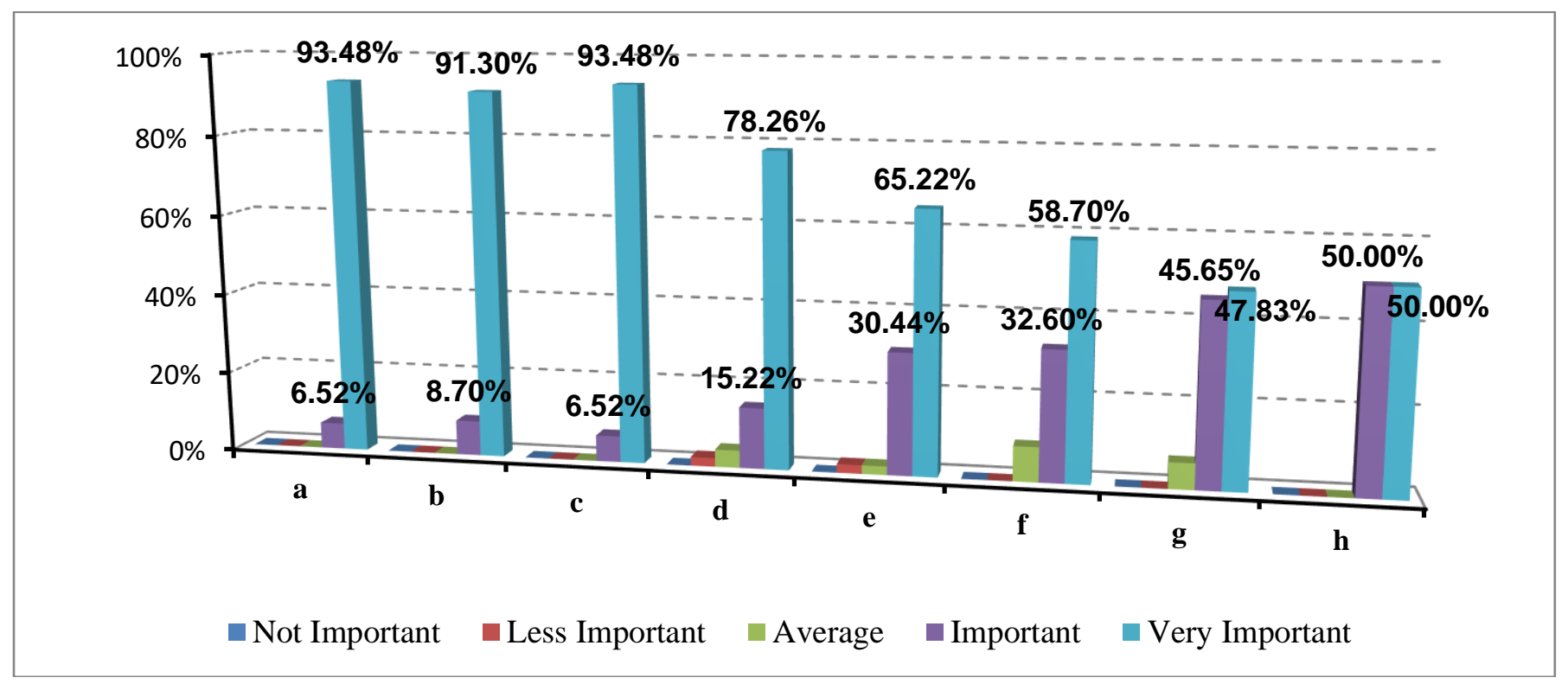

Note:

a. Introduction to Accounting b. Conceptual Framework of Accounting

c. Basic Accounting Procedures 
d. Journal

e. Ledger

f. Bank Reconciliation Statement

g. Capital and Revenue Transaction

h. English skills combine with Accounting Knowledge

\section{REFERENCES}

Al-Tamimi, A. S., \& Shuib, M. (2010). Investigating the English Language Needs of Petroleum Accounting Students at Hadhramout University of Science and Technology. The Asian ESP Journal, 6(1), 6-34.

Alwasilah, A. C. (2009). Pokoknya Kualitatif. Dasar-dasar Merancang dan Melakukan Penelitian Kualitatif. Jakarta. PT. Dunia Pustaka Jaya.

Ambrose, S. Et al. (2010). How Learning Works: Seven Research-Based Principles for Smart Teaching, San Francisco, CA : Jossey-Bass, [2010] C2010

Brindley, G. (1989). The role of needs analysis in adult ESL programme design. In R. K.

Bingham and Conner, (2010). The New Social Learning: A Guide to Transforming Organizations Through Social Media, Berrett-Koehler Publishers, Sep 13, 2010

Brown. J. D. (2001). Using surveys in language program. Cambridge: Cambridge University Conelly, E.M and Clandinin, D.J. 1988. Teachers as Curriculum Planners. New York: Teachers College, Columbia University.

Connelly, F. M., \& Clandinin, D. J. (1988). Teachers as curriculum planners: Narratives of experience. New York: Car-negie Cooperation.

Dudley-Evans, T., \& St John, M. 1998. Developments in ESP: A Multi- disciplinary Approach. Cambridge: Cambridge University Press.

Frankel, J, R., \& Wallen, N, E. (2006). How to design and evaluate and research in education with PowerWeb $\left(6^{\text {th }}\right.$ ed). New Yorlk, NY: McGrawHill.

Flowerdew, J., and Miller, L. (1996). 'Lectures in a second language: notes towards a cultural grammar.' English for Specific Purposes, 15 (2), 121-40

Gatehouse, K. (2001) Key issues in English for Specific Purposes: (ESP) Curriculum development. TESL Journal Vol. VII, No.10, October 2001, http://www.iteslj.org/Articles/Gatehouse-

ESP.html, Diakses tanggal 10 Maret, 2018.

Hancock, B., Ocklefor, E., \& Windrige, K. (2009). An Introduction to Qualitative Research. The NIHR RDS EM / YH

Hutchinson, T., and Waters, A. (1987). English for Specific Purposes: A Learner Centered Approach. Cambridge University Press.
Hymes, D., 'On Communicative Competence' in Sociolinguistics, Pride, J. B. and Holmes, J. (eds.), Penguin, 1972

Hashimoto, Mitsunori. (1992). English for Specific Purposes (ESP) and the Teaching of Financial English

Holmes, J., 'Needs Analysis: A rationale for course design' in the ESPecialist, No. 3, July 1996

Heyland, K. (2002). Specificity Revisited: how far should we go? City University of Hongkong (2002)

Hyland, K.(2006). 'Disciplinary differences: language variation in academic discourses.' In K. Hyland and M. Bondi (eds), Academic discourse across disciplines. Frankfurt: Peter Lang.

Ibbotson, M. (2008). Cambridge English for Accounting. Cambridge: Cambridge University Press.

Kennedy, C., and Bolitho, R. (1984). English for Specific Purposes. Hong Kong. Macmillan Publishers Ltd.

Kvale, S.(1996). Interviews: An introduction to qualitative research interviewing. Thousand Oaks, CA: Sage.

McDonough, J. (1984). ESP in perspective: A practical guide. London and Glasgow: Collins Educational.

Munby J. (1978). Communicative syllabus design: A sociolinguistic model for defining the content of purpose-specific language programmes. London: Cambridge University Press.

Nunan, D. (1988). The Learner-Centered Curriculum. Britain: Cambridge University Press.

Payne and Turner, (1999). Dyslexia Parents' and Teachers' Guide: Multilingual Matters Limited Press, Sydney.

Richards, J.C. (2001). Curriculum Development in Language Teaching. UK: Cambridge University Press.

Richterich, R., and Chancerel, J. (1980). Identifying the needs of adults learning a foreign language. Oxford: Pergamon Press.

Robinson, P. (1991). ESP today: A practitioner"es guide. New York: Prentice Hall.

Setiyadi, A. B. (2006). Metode Penelitian Untuk Pengajaran Bahasa Asing. Bandung. Graha Ilmu.

Silverman, D. (2005). Doing Qualitative Research. London: SAGE Publications Ltd.

Songhori, M.H. (2008). Introduction to Needs Analysis. English for Specific Purposes World, Issue 4, [online], (www.espworld.info).

Soriano, F. I., \& University of Michigan. School of Social Work. (1995). Conducting needs assessments: A multidisciplinary approach. Thousand Oaks: Sage Publications.

Spratt, P., and William. (2005). The TKT (Teaching Knowledge Test) Course.Cambridge: Cambridge University Press. 
Sugiyono. (2008). Metode Penelitian Kunatitatif Kualitatif dan R\&D. Bandung Alfabeta.

Suyadi. (2016). English for Specific Purposes for Accounting Students. International Journal of Innovation and Research in Educational Sciences Volume 3, Issue 2, ISSN (Online): 2349-5219

West, R. (1994). „Needs Analysis in Language Teachinge. Language Teaching Journal No. 27.

Yanto, A. (2005). Kesiapan Kerja Siswa Program Keahlian Listrik (Studi Kasus di SMK N 2 Pengasih dan SMK Ma"earif 1 Wates Kulon progo Yogyakarta Tahun Ajaran 2004/2005). Skripsi $\quad$ : $\quad$ FT UNY.

Yusuf Muri .2013. Metode Penelitian. Padang: UNP Press. 